\title{
Use of the Diffusion of Innovation Model in venous ulcers by specialized professionals
}

\author{
Utilização do Modelo Difusão da Inovação em úlceras venosas por profissionais especializados \\ Empleo del Modelo de Difusión de Innovación entre profesionales de salud en el tratamiento y la \\ prevención de úlceras venosas
}

\section{Eline Lima Borges', Maria Helena Larcher Caliri", Vanderlei José Haas"II, Aidê Ferreira Ferraz ${ }^{\mathrm{IV}}$, Josimare Otoni Spirav ${ }^{\mathrm{v}}$, Ana Carolina Tyrone ${ }^{\mathrm{v}}$}

'Universidade Federal de Minas Gerais, School of Nursing, Postgraduate Program in Nursing. Belo Horizonte, Minas Gerais, Brazil. "Universidade de São Paulo, Ribeirão Preto College of Nursing, Postgraduate Program in Primary Care Nursing. Ribeirão Preto, São Paulo, Brazil.

II' Universidade Federal do Triângulo Mineiro, Postgraduate Program in Health-Care. Uberaba, Minas Gerais, Brazil.

IV Universidade Federal de Minas Gerais, School of Nursing. Belo Horizonte, Minas Gerais, Brazil.

${ }^{\vee}$ Universidade Federal de Minas Gerais, Specialization Course of Nursing in Enterostomal Therapy. Belo Horizonte, Minas Gerais, Brazil.

How to cite this article:

Borges EL, Caliri MHL, Haas VJ, Ferraz AF, Spira JO, Tyrone AC. Use of the Diffusion of Innovation Model in venous ulcers by specialized professionals. Rev Bras Enferm [Internet]. 2017;70(3):610-7. DOI: http://dx.doi.org/10.1590/0034-7167-2016-0235

\section{Submission: 06-23-2016 Approval: 01-04-2017}

\section{ABSTRACT}

Objective: To analyze the influence of the evidence and of the opinion of peers on the decisions of specialists regarding the agreement with recommendations for prevention and treatment of venous ulcer. Methods: This is a quasi-experimental study with two interventions: provision of studies with the evidence of the recommendations and provision of the opinion of peers, with sample of 73 specialized doctors and nurses. Delphi technique was used in the search for agreement, with three rounds. Results: The participants evaluated 82 recommendations organized into eight domains: evaluation of patient and wound; documentation of clinical findings; care with the wound and surrounding skin; indication of dressing; use of antibiotics; improvement of venous return and prevention of recurrence; referrals of patients; and professional training. The interventions resulted in statistically significant changes in four domains. Conclusion: The interventions were able to change the opinion of participants, leading them to agreement regarding the recommendations, regardless of the level of evidence. Descriptors: Varicose Ulcer; Practice Guidelines as Topic; Delphi Technique; Diffusion of Innovation; Health Personnel.

\section{RESUMO}

Objetivo: Analisar a influência das evidências e da opinião dos pares sobre as decisões dos especialistas quanto à concordância com recomendações para prevenção e tratamento de úlcera venosa. Método: Estudo quase-experimental com duas intervenções: fornecimento de estudos com as evidências das recomendações e opinião dos pares, com amostra de 73 especialistas médicos e enfermeiros. Utilizou-se a técnica Delphi na busca de concordância, com 3 rodadas. Resultados: Os participantes avaliaram 82 recomendações organizadas em 8 domínios: avaliação do paciente e de sua lesão; documentação dos achados clínicos; cuidado com a lesão e pele ao redor; indicação da cobertura; uso de antibiótico; melhoria do retorno venoso e prevenção de recidiva; encaminhamentos dos pacientes; e capacitação profissional. As intervenções resultaram em mudanças estatisticamente significativas em 4 domínios. Conclusão: As intervenções foram capazes de modificar a posição dos participantes, levando-os para a posição de concordância a respeito das recomendações, independentemente do nível de evidência.

Descritores: Úlcera Varicosa; Guias de Prática Clínica como Assunto; Técnica Delfos; Difusão de Inovações; Profissional de Saúde.

\section{RESUMEN}

Objetivo: Analizar la influencia de evidencias y la opinión de dúos en las decisiones de los profesionales de salud sobre el consenso de las recomendaciones para prevenir y tratar las úlceras venosas. Método: Estudio cuasi-experimental con dos intervenciones: acceso a estudios con evidencias de las recomendaciones y de la opinión de los dúos, con el muestreo de 
73 profesionales entre médicos y enfermeros. Se empleó el método Delphi para buscar un consenso, con tres turnos. Resultados: Los participantes analizaron 82 recomendaciones organizadas en ocho dominios: el examen del paciente y de su lesión; la documentación de los resultados clínicos; el cuidado de la lesión y de la piel alrededor; la indicación de la cobertura; el empleo de antibióticos; la mejora del retorno venoso y la prevención de recaídas; el traslado de los pacientes; y la capacitación profesional. Las intervenciones presentaron valores estadísticamente significativos en cuatro dominios. Conclusión: Las intervenciones produjeron cambios de opinión en los participantes, quienes llegaron a un consenso sobre las recomendaciones, independiente del nivel de evidencia.

Descriptores: Úlcera por Estasis; Guías de Práctica Clínica como Tema; Técnica Delfos; Difusión de Innovación; Profesional de Salud.

CORRESPONDING AUTHOR ElineLima Borges E-mail: elineufmg@gmail.com

\section{INTRODUCTION}

Leg ulcers, according to the underlying disease, can be categorized into vascular, metabolic, infectious, neoplastic, traumatic, due to hematologic disease and other causes. In several countries, the primary etiology of these ulcers is the peripheral artery disease of lower limbs, especially venous insufficiency ${ }^{(1)}$. The latter are called venous or varicose.

Venous ulcers, in most cases, arise from the insufficiency of the deep and superficial venous system and incompetence of the perforator veins. There is also incompetence in the gastrocnemius muscle pump (calf muscle), because the venous pressure, during walking or exercise, does not occur, resulting in retrograde flow. These ulcers have high recurrence rate ${ }^{(2)}$.

For approaching patients with venous ulcer, the professional must carry out an appropriate vascular evaluation, which requires observation of the anatomical and functional state of the superficial, deep, and perforator venous systems and of the arterial system, in addition to verification of the presence of signs of systemic disease ${ }^{(3)}$. This is the first step to achieve final success, i.e., the complete healing of the wound.

The care to these patients must be centered on measures that increase venous return, control systemic factors, and provide an appropriate environment in the wound to promote healing. Venous ulcer care requires the existence of basic treatment of venous hypertension. After wound healing, emphasis should be given to the adoption of new behaviors, habits, and lifestyle, such as the continued use of compression therapy and alternation between periods of rest and walking, to control venous insufficiency and, consequently, to prevent the emergence of new wounds ${ }^{(4)}$.

The scientific advances in this area, verified by national and international studies, have not yet been translated into effective and widespread changes in the care to people with venous ulcers in Brazil. In this scenario, one can still see many doubts about which would be the best treatments to these cases, generating diversity of conducts and also different results regarding the effectiveness of the care provided to the patient.

Although professionals implement conducts always seeking the healing of venous ulcers and the well-being of the patient, they are not always based on scientific evidence. The diversity of behaviors and little observance of the scientific basis by already defined guidelines can often cause in the professional feelings of insecurity and uncertainty as to the best option for the care and treatment to be adopted. Such occurrence results in a clinical practice anchored in a paradigm that values first and foremost the unsystematic observations about the basic mechanisms of the diseases and in the association of almost intuitive personal experiences of the common sense, under the prevailing authoritarianism in professional training and in the transfer of traditional specialized information.

To transform scientific evidence in actions in clinical practice, it is essential to understand how the diffusion of knowledge occurs. This transformation can be understood in the light of Rogers' Diffusion of Innovation Model ${ }^{(5)}$. It establishes that an individual's decision process on an innovation consists of a series of actions, which involve five stages: 1. Knowledge Stage; 2. Persuasion Stage; 3. Decision Stage; 4. Implementation Stage; 5. Confirmation Stage.

Given the above, this study aimed to analyze the influence of the evidence and of the opinion of peers on the decisions of experts regarding the agreement with recommendations for prevention and treatment of venous ulcer.

\section{METHODS}

\section{Ethical aspects}

This study was approved by the Research Ethics Committee of the Ribeirão Preto College of Nursing of University of São Paulo. The ethical requirements set in Resolution 466/2012 of the National Health Council were met, including the signing of informed consent form by the participants.

\section{Study design, location, and period}

This is a quasi-experimental study for analysis of two interventions: provision of studies with the evidence of the recommendations; provision of the opinion of peers. The study included participants from several Brazilian states (Rio Grande do Sul, Paraná, Santa Catarina, São Paulo, Minas Gerais, Rio de Janeiro, Goiás, Rio Grande do Norte, Ceará, Pernambuco) and lasted 10 months.

\section{Sample, inclusion and exclusion criteria}

The sample consisted of 73 professionals, with 13 nurses members of the Brazilian Society of Nursing in Dermatology (SOBENDE), 18 enterostomal therapists members or not of the Brazilian Association of Enterostomal Therapy (SOBEST), 17 dermatologists, and 25 angiologists and vascular surgeons.

Professionals with specific training in the medical or nursing area and experience in meeting patients with venous ulcers, living in Brazil during the data collection period, were included. Those who have not met all the inclusion criteria were excluded. 


\section{Study protocol}

The evaluation of the experts' agreement with the recommendations was investigated using a survey with Delphi technique. This is a group facilitation technique that seeks to obtain opinion of experts, usually called judges, and a consensus by a series of structured questionnaires, which are anonymously filled out by participants effectively engaged in the area where the study is being developed ${ }^{(6)}$. To provide a representative information, some studies have used more than 60 experts, while others used around $15^{(6)}$.

The interactive questionnaire circulates several times in the group of experts. In every round of the questionnaire, the answers are analyzed by the researcher based on the measures of position and dispersion of scores. The results are presented to the group in the following round, so that they can rethink their positions before the numeric responses and justifications presented by the other participants, returning it next. The technique helps an interactive process of several steps, planned to transform the group's opinion in consensus ${ }^{(7)}$.

To meet the study design and implementation of interventions, three rounds of the survey were carried out, using the postal service as the means of communication between researcher and experts.

The data collection instrument contained 82 recommendations supported on scientific evidence for the care of people with venous ulcers. The recommendations and their strength of evidence were identified by systematic review of primary studies and analysis of four guidelines on the treatment of patients with venous leg ulcers used in other countries, previously carried out by the authors of the research.

For the analysis of the professionals' proportion of agreement, the recommendations were grouped into eight domains, each one having a different total (T) of recommendations: 1. evaluation of patient and wound $(T=21) ; 2$. documentation of clinical findings $(T=3) ; 3$. care with the wound and surrounding skin $(T=10) ; 4$. indication of dressing $(T=10)$; 5 . use of antibiotics $(T=3) ; 6$. improvement of venous return and prevention of recurrence $(T=28)$; 7 . referrals of patients $(T=4)$; 8. professional training $(T=3)$. In its first part, the instrument included the participants' personal and professional data.

Each recommendation was evaluated according to a 5-point scale (Likert-type), with qualitative description ranging from 1 ("Totally disagree") to 5 ("Totally agree"), and with three intermediate points: 2 ("Partly disagree"); 3 ("Neither agree nor disagree") and 4 ("Partly agree"), to measure the participants' agreement.

Aiming to help the detection of changes of position arising from the interventions carried out in the second and third moments, we chose to recode the five original positions to only three: "totally disagree" and "partially disagree" for disagreement; "totally agree" and "partially agree" for agreement, in addition to the position of neutrality.

The pretest of the instrument was held with the participation of a dermatologist and three nurses, who suggested the writing correction of one recommendation.

In the first round, each participant received the recommendations for the topical treatment of venous ulcer, without the evidence that help them, and were oriented to evaluate them and mark their decision before each recommendation, as well as to return the material to the researcher. Figure 1 shows the summary of the rounds.

The instrument was forwarded to 73 participants in a 45day period, according to the date of acceptance to participate in the study. The first round required five months.

The second round of the Delphi technique required three months and 15 days. In this step, we carried out the first intervention and sent the recommendations accompanied by the evidence that based their construction, as well as the references of the selected studies. Participants marked again their decision regarding each presented recommendation and returned the material to the researcher.

The third round required two months. Participants received, in addition to the instrument with the recommendations and evidence, the result of their own opinion (reproduction of the instrument of the second round) and the summary of the opinion of colleagues participating in the study (second intervention), presented in chart showing the percentage of "totally disagree, partly disagree, neither agree nor disagree, partially agree, totally agree" for each recommendation. From that, they were instructed to reevaluate their decision before each recommendation presented.

At the end of data collection, we verified the loss of 15 $(20.5 \%)$ participants between the first and last rounds.

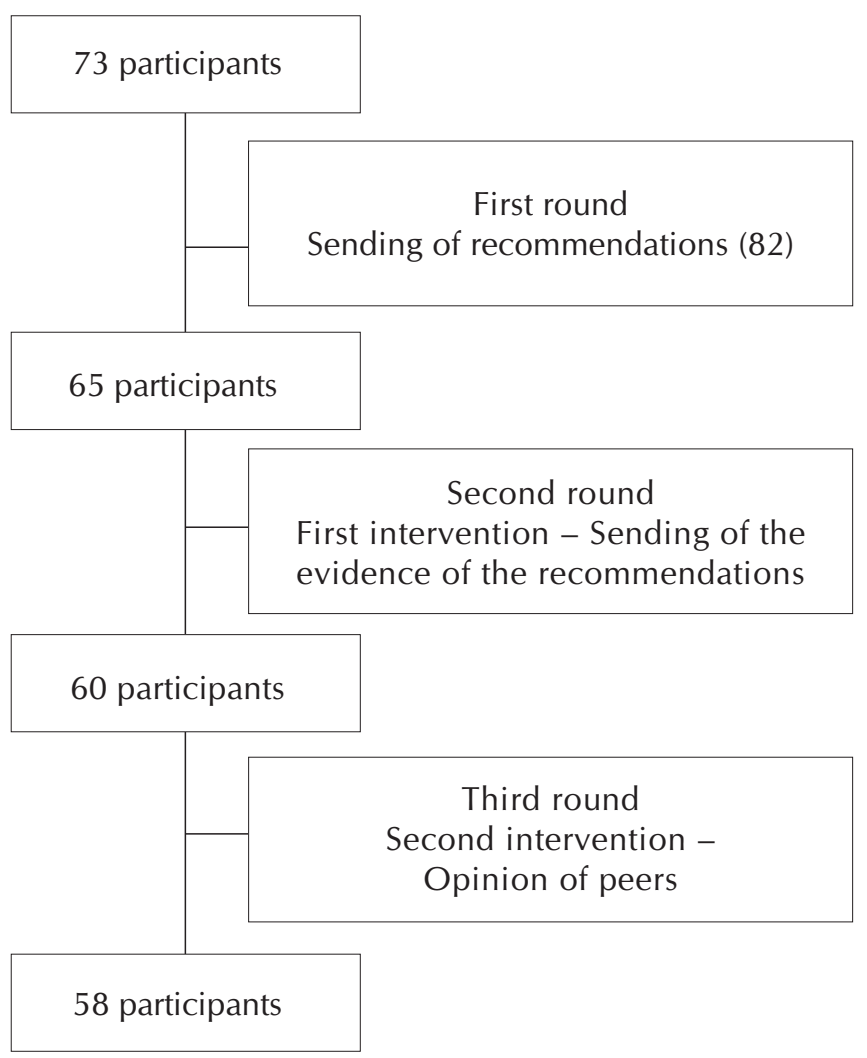

Figure 1 - Flowchart of the summary of rounds of Delphi technique 


\section{Analysis of results and statistics}

Data were analyzed in the Statistical Package for Social Sciences (SPSS). We performed exploratory univariate analysis for each of the recommendations in the three different moments, to analyze the frequency distributions. Contingency tables were obtained for unifactorial repeated measures analysis of associations and variance, aiming to analyze the impact of the presentation of the evidence and opinion of peers on the opinion of participants.

A unifactorial repeated measures analysis of variance was carried out to analyze statistically significant changes of the average proportions of "agreement," "disagreement, " and "neutrality" positions. In this analysis, the three moments were considered as the within subject factor, since it was not intended, at that time, to analyze the interactions between this factor and any other variables associated with participants (between subject factor), such as profession or practice time. Therefore, a GLM (General Linear Models) procedure was carried out with only one factor, for obtaining the average proportion of agreements in the eight domains.

In the multiple comparison analysis, Bonferroni correction was used. In each of the domains, the sphericity condition (similar to the homogeneity of variance in a simpler traditional ANOVA) was satisfied.

\section{RESULTS}

Of the professionals who answered the instrument, in the first moment of the research, $39(60 \%)$ were females and, of these, most $(71.8 \%)$ were nurses. The only category with most males $(69.2 \%)$ was "angiologist."

The interventions resulted in changes of position of the professionals in relation to the recommendations. Some domains presented change in the standard deviation (s) with interventions one and two, presented in the second and third moments (Table 1).

Despite the changes observed for most domains, as can be seen in the average proportions of "agreement," "disagreement," and "neutrality" positions in each of the domains, the sphericity condition was satisfied (Table 2).

In the quasi-experimental study, the dependent variable in the first moment (pre-intervention) identified that the best agreements - in descending order for the domains - were in domain 2 (documentation of clinical findings), domain 8 (professional training), domain 1 (evaluation of patient and wound), domain 5 (use of antibiotics), domain 3 (care with the wound and surrounding skin), domain 7 (referral of patients), domain 6 (improvement of venous return and prevention of recurrence), and domain 4 (indication of dressing), respectively.

On the second moment - after the first intervention - there was increase of those in agreement position in all domains. Domain 2 remained as the most accepted $(=95.40, s=11.59)$, and domain 4 , as the least accepted $(=34.48, s=26.10)$.

On the third moment - after the second intervention there was increase of participants in agreement position in most domains, except in domain 4.
Table 1 - Distribution of average proportions of the positions of participants in the three moments for the eight domains

\begin{tabular}{cccc}
\hline & \multicolumn{3}{c}{ Position } \\
\cline { 2 - 4 } Moment & $\begin{array}{c}\text { Agreement } \\
\bar{X}(\mathbf{s})\end{array}$ & $\begin{array}{c}\text { Neutrality } \\
\bar{X}(\mathbf{s})\end{array}$ & $\begin{array}{c}\text { Disagreement } \\
\bar{X}(\mathbf{s})\end{array}$ \\
\hline Domain 1 & & & \\
Moment 1 & $85.7(12.80)$ & $7.64(8.96)$ & $6.57(8.41)$ \\
Moment 2 & $90.31(9.14)$ & $5.50(7.71)$ & $3.61(5.52)$ \\
Moment 3 & $92.61(9.32)$ & $4.68(7.85)$ & $2.71(4.73)$ \\
Domain 2 & & & \\
Moment 1 & $94.83(12.17)$ & $3.45(10.24)$ & $1.72(7.45)$ \\
Moment 2 & $95.40(11.59)$ & $3.45(10.24)$ & $1.15(6.14)$ \\
Moment 3 & $96.55(10.24)$ & $2.30(8.52)$ & $1.15(6.14)$ \\
Domain 3 & & & \\
Moment 1 & $74.31(17.08)$ & $20.86(16.68)$ & $4.66(8.21)$ \\
Moment 2 & $77.93(17.45)$ & $19.66(16.43)$ & $1.55(4.10)$ \\
Moment 3 & $80.17(14.93)$ & $18.97(14.95)$ & $0.86(2.83)$ \\
Domain 4 & & & \\
Moment 1 & $32.07(21.17)$ & $58.45(25.53)$ & $9.14(13.41)$ \\
Moment 2 & $34.48(26.10)$ & $59.14(29.40)$ & $6.03(11.23)$ \\
Moment 3 & $33.28(25.02)$ & $62.59(27.05)$ & $4.14(7.50)$ \\
Domain 5 & & & \\
Moment 1 & $82.76(21.85)$ & $10.92(16.97)$ & $6.32(15.87)$ \\
Moment 2 & $86.78(18.67)$ & $10.92(16.97)$ & $1.72(7.45)$ \\
Moment 3 & $87.93(17.32)$ & $10.34(15.56)$ & $1.15(6.14)$ \\
Domain 6 & & & \\
Moment 1 & $54.99(18.00)$ & $36.76(21.82)$ & $8.25(10.56)$ \\
Moment 2 & $60.84(18.86)$ & $32.64(20.36)$ & $4.74(8.53)$ \\
Moment 3 & $62.32(16.89)$ & $34.14(18.55)$ & $3.26(6.53)$ \\
Domain 7 & & & \\
Moment 1 & $71.12(26.82)$ & $14.22(21.52)$ & $14.22(19.03)$ \\
Moment 2 & $82.33(21.46)$ & $10.78(18.20)$ & $6.47(13.70)$ \\
Moment 3 & $86.21(17.00)$ & $8.62(15.21)$ & $5.17(10.22)$ \\
Domain 8 & & & \\
Moment 1 & $93.10(14.92)$ & $1.15(6.14)$ & $5.17(12.17)$ \\
Moment 2 & $94.83(12.17)$ & $1.72(7.45)$ & $2.30(8.52)$ \\
Moment 3 & $97.13(9.44)$ & $0.57(4.38)$ & $2.30(8.52)$ \\
\hline
\end{tabular}

Table 2 - Results of the analysis of variances (repeated measures) of the proportions of agreement in the three moments, for the eight domains

\begin{tabular}{cccc}
\hline & \multicolumn{2}{c}{ Moment 1} & Moment 2 \\
\cline { 2 - 4 } Domains & Moment 2 & Moment 3 & Moment 3 \\
& $\overline{\mathrm{X}}_{2}-\overline{\mathrm{X}}_{\mathbf{1}}(\mathbf{p})$ & $\overline{\mathrm{X}}_{3}-\overline{\mathrm{X}}_{\mathbf{1}}(\mathbf{p})$ & $\overline{\mathrm{X}}_{3}-\overline{\mathrm{X}}_{\mathbf{2}}(\mathbf{p})$ \\
\hline Domain 1 & $-4.598^{*}(0.004)$ & $-6.897^{*}(0.000)$ & $-2.299^{*}(0.000)$ \\
Domain 2 & $-0.575(1.000)$ & $-1.724(0.781)$ & $-1.149(0.477)$ \\
Domain 3 & $-3.621(0.090)$ & $-5.862^{*}(0.001)$ & $-2.241(0.172)$ \\
Domain 4 & $-2.414(1.000)$ & $-1.207(1.000)$ & $1.207(1.000)$ \\
Domain 5 & $-4.023(0.541)$ & $-5.172(2.85)$ & $-1.149(0.477)$ \\
Domain 6 & $-5.850(0.78)$ & $-7.328^{*}(0.002)$ & $-1.478(0.745)$ \\
Domain 7 & $-11.207^{*}(0.000)$ & $-15.086^{*}(0.000)$ & $-3.879(0.056)$ \\
Domain 8 & $-1.727(1.000)$ & $-4.023(0.211)$ & $-2.299(0.133)$
\end{tabular}

Note: *The difference between the means of the three moments is significant for a $=0.05$ 


\section{DISCUSSION}

By analyzing the average agreement of the participants in the domains, we observed that, in the first and second moments, the three domains most accepted by the participants were domains 2 (documentation of clinical findings), 8 (professional training), and 1 (evaluation of patient and wound), respectively; and, in the third moment, domains 8,2 , and 1 , respectively. In the three moments, the least accepted domain was domain 4 (indication of dressing).

The results obtained in this research confirm Rogers' statement ${ }^{(5)}$ : the diffusion of an innovation is a social process that is made between interpersonal networks or channels. In this research, a new knowledge from the recommendations is represented as an innovation, when perceived by the professionals who did not know it.

The interventions showed statistically significant changes in domains 1 (evaluation of patient and wound), 3 (care with the wound and surrounding skin), 6 (improvement of venous return and prevention of recurrence), and 7 (referrals of patients). In domain 1 (evaluation of patient and wound), the change took place in the second $(p=0.004)$ and third moments $(p=0.000)$. In domain 3 (care with the wound and surrounding skin), the differences were found in moment three, after the two interventions $(p=0.001)$. This same fact occurred in domain 6 (improvement of venous return and prevention of recurrence) $(p=0.002)$. In domain 7 (referrals of patients), there was statistically significant change only after the first intervention $(p=0.001)$. Domain 8 became the most accepted $(=97.13, s=9.44)$ and domain 4 remained the least accepted $(=33.28, s=25.02)$.

When participants took notice of the basis of the recommendations, regardless of the level of evidence, the observed trend was of increase in the agreement of experts. The evaluation of the agreement confirmed that the group's opinion influenced the individual decision about the agreement. We verified that the group was able to cause changes in the individual's position regarding the new knowledge.

In domain 1 (evaluation of patient and wound), we observed that, despite the topic being part of the basic education of medical and nursing professionals, preceding the formation of the expert, deficiencies arising from the graduation can inhibit the diffusion of the knowledge on the subject ${ }^{(5)}$.

The recommendations with lower percentages of agreement referred to the performance and evaluation of result of the ankle-brachial pressure index. The opinion of participants can be explained by the very process of diffusion of innovation, because the proposed recommendations seem to be perceived as complex and risky, which makes them more difficult to be understood and adopted ${ }^{(5)}$. The lack of compatibility of the recommendations with the reality of health services in Brazil, which do not have the Doppler vascular manual (required equipment), may have led the professionals to disagree with these recommendations.

The same difficulties presented by the participants of this research have been found in a review carried out to identify the gaps in the knowledge shown by nurses regarding the care of patients with venous ulcers. In the initial search of the literature, 174 citations have been identified on MEDLINE, $\mathrm{Cl}$ NAHL, and Cochrane Library, and, of these, 16 articles constituted the sample. In the analysis of these articles, the authors observed the lack of knowledge related to venous physiology, healing process, and how this affects the care and outcome of treatment of venous ulcer. Therefore, there is a need for developing educational programs to remedy the gaps identified ${ }^{(8)}$.

In domain 2 (documentation of clinical findings), the recommendations establish the register of clinical findings, which reinforces what is advocated by the clinical examination and by the ethical code of medical and nursing professionals. Currently, this topic has been emphasized in the disciplines of these courses due to the increase in the number of legal processes generated by users when feeling injured or poorly treated. One of the ways professionals have of defending themselves is to prove their actions and decisions contained in the records.

The use of standardized nursing languages systems is essential to ensure clear and systematic records that provide safety to the nursing practice, requiring its judicious use and with emphasis placed on its true purpose: naming phenomena of interest to the discipline of nursing ${ }^{(9)}$.

In domain 3 (care with the wound and surrounding skin), the highlight was the recommendation on the use of Essaven gel on the skin, obtaining the lowest agreement in this domain. This recommendation is supported by three studies of evidence II, made in Italy. However, as in Brazil a similar of this product (Reparil ${ }^{\otimes}$ gel) is not very used for reducing the flow of carbon dioxide (CO2) and increasing the pressure of oxygen (PO2) on the skin, the professionals have no knowledge and experience of its use, which probably intervened in the large number of answers in neutrality position. A new knowledge, coming or not from research results, is represented as an innovation when perceived by the professionals who did not know it, even if in fact it is not recent ${ }^{(5)}$.

Domain 4 (indication of dressing) obtained low agreement of professionals. Among the attributes of an innovation, the issue of perceived advantage contributes to explain most part of this result. The professionals who treat patients with venous ulcers may not yet have realized the advantage of using dressings that keep the wound bed moist, with consequent increased rate of healing and reduced number of changes. Another limitation is that professionals tend to evaluate the initial cost of the treatment, without considering other benefits, such as the reduction of changes, reduction of work hours required to perform the procedure with the innovation, and reduction of time for healing.

We observed that most participants were in "neutrality" position in most recommendations, and that doctors were more neutral than nurses. The result might be explained by the fact that the content about topical therapy of wounds, including cleaning, debridement, and dressing use, is part of the program of the specialization courses of nurses, in addition to this topic also appearing on the curriculum of some undergraduate courses. This situation was present in the three moments, probably because the professionals do not have experience in 
the comparative use of the products, not being possible, thus, to meet the characteristic of observability of innovation.

The two recommendations with the highest percentages of agreement propose: using a simple, non-adherent, low-cost dressing that is accepted by the patient; using hydrocolloid or foam dressings in painful ulcers. This result can be explained by the low complexity of the first recommendation, general and not specific, which is considered simple and low-cost. This can lead the professional to use a dressing that is not the best to promote healing. The treatment of venous ulcer, as with other wounds, requires an optimal healing environment, obtained with the maintenance of physiological moisture and occlusion, but also demands the improvement of venous return with the use of elastic or inelastic compression therapy ${ }^{(10)}$.

The second recommendation approaches dressings existing in the national market for several years, e.g., the hydrocolloid, used for more than 30 years in the treatment of wounds. There are several studies, including national ones, about these dressings, mainly case reports describing the experience of professionals with them. A systematic review study about hydrocolloid $^{(11)}$, performed by Brazilian researchers and available in the Cochrane Library, confirms this fact. The exchange of experience between professionals, highlighting the positive aspects of innovation, makes it more accepted by the group.

Also, hydrocolloid and hydropolymer dressings are used in different institutions in Brazil; some, since the 1980s. This probably provided experience to professionals to support their decision, raising the level of agreement. However, other attributes, such as "testability" and "observability," helped hydrocolloid to be used in clinical practice. To this end, it was necessary to overcome the resistance of professionals regarding its characteristics, such as impermeability, formation of yellow gel, and sharp odor, besides the permanence on the wound for several days $^{(12)}$. Professionals had to replace the paradigm of dry wound healing by moist wound healing. Another factor that probably helped the acceptance of hydrocolloid was the improvement of the healing process response, such as the autolytic debridement, reduction of wounded area, and report of improvement in pain by the patient or reduction in analgesic consumption ${ }^{(11)}$.

The compatibility of an innovation with an idea that preceded it can speed up or slow down its adoption. Old ideas are the main mental tools used by individuals to evaluate new ideas and assign a meaning to them. Previous practice provides a standard against which the innovation will be interpreted, thus decreasing the uncertainty about $\mathrm{it}^{(5)}$.

Many managers justify the non-implementation and implementation of interactive wound dressings at health services because of their high $\cos ^{(10)}$. A strategy to optimize resources is using dressings correctly and appropriately, based on evidence.

In domain 5 (use of antibiotics), the recommendation on the indications of mupirocin stood out, obtaining the lowest percentage of agreement in the three moments. Most doctors agreed to use the product. It seems that, despite the risks arising from its use, the professionals believe in the good results obtained. So far, there is no available evidence to support the routine use of topical or systemic antibiotics in the promotion of venous ulcers healing. Before the growing problem of bacterial resistance to antibiotics, the recommendation is that antibacterial preparations should be used only in clinical infection cases, and not to control bacterial colonization ${ }^{(13)}$.

In domain 6 (improvement of venous return and prevention of recurrence), the recommendation that advocates riskfree and non-innovative general measures for the prevention of recurrences obtained total agreement of participants. This is possibly because this required knowledge is part of the general practitioner training in the medical and nursing areas.

It is observed that, in this domain on improvement of venous return and prevention of recurrence, many recommendations about the use of compression therapy address products not available or not easily found in the national market, such as the radiant heat bandage, the short-stretch bandage, and the four-layer bandaging system ${ }^{(14)}$. Compression therapy can be inelastic or elastic, and the elastic system consists of bandages and compression stockings. These products are recommended in recent publications on the subject ${ }^{(15)}$. In Brazil, the most used system is the inelastic compression therapy of Unna's boot, and its most common form is the application of Unna's paste in the crepe bandage.

The attributes of innovation regarding compatibility, complexity, testability, and observability may have intervened in this domain, not allowing the relative advantages obtained in the international context to be recognized by the study participants. If professionals do not have access to the products to test them for a limited time or evaluate the results arising from their use, the advancement of innovation in the diffusion process becomes difficult.

Another aspect observed is the ignorance on the part of professionals about which products are available in the national market. This situation hinders the adoption of innovation for compression therapy, since the first stage of the decision-making process for adopting innovation is knowledge $\mathrm{e}^{(5)}$.

In domain 7 (referrals of patients), the recommendation that advocates referring patients with ulcer associated with dermatitis for specific contact test stood out, obtaining the lowest percentage of agreement and the greatest neutrality by professionals.

The recommendation that guides about referrals to medical specialist under certain conditions obtained agreement greater than $90.0 \%$, exemplifying the importance of teamwork in the care to patients with venous ulcer.

When there is teamwork and the specialists are called in previously established specific cases, costs tend to reduce and the care capacity of health services tends to increase ${ }^{(3)}$.

In domain 8 (professional training), all recommendations obtained agreement above $90.0 \%$. The recommendation most accepted by participants advocates that clinical examination and ulcer evaluation should be performed by a doctor or nurse, trained and experienced in the treatment of venous ulcer.

It should be stressed that nurses have legal support to perform care to people with venous ulcer. For example, one can resort to Resolution no. 501 of the Federal Nursing Coun$\mathrm{cil}^{(16)}$, which shows the professional skills of nursing professionals in the prevention and treatment of cutaneous lesions. 
However, what is recommended is not always found in Brazilian institutions. This fact was confirmed in a study conducted in the city of Goiânia-GO, involving patients in treatment of vascular ulcers, met in 49 bandaging rooms, composing a sample of 58 people. The results showed a population with deteriorated wounds and treatment at odds with the main international recommendations ${ }^{(17)}$.

In the area of prevention and treatment of people with venous ulcer, one priority is the need to expand the concept of evidence-based practice, so that professionals can recognize and incorporate the results of relevant research and other evidence in their clinical practice. They need to have specific and deep knowledge on the treatment of venous ulcers and on the evidence that supports this practice.

\section{Study limitations}

The study relied on convenience sample without a priori calculation, which limits the external validity of the findings.

\section{Contributions to the fields of nursing, health, or public policy}

Analyzing in greater depth the evidence in the treatment and prevention of venous ulcer is a very relevant action, needed (and also urgent) in the health area, to clearly define the issues around the difficulties for using scientific evidence and to provide a systematic targeting to find and discover possible solutions for professional decisions and patient healing. In this sense, it is important to stress the need for the involvement of professionals in the implementation of any recommendation, protocol, or clinical guideline to the reality in which it will be implemented. The results of this research confirmed the relevance of two strategies for adoption of new knowledge.

\section{CONCLUSION}

The two interventions carried out in this study were able to trigger positive changes with increased frequency in the agreement position in almost all domains, except in domain 4 (indication of dressing), observed in the third moment. In the other domains, the average proportion of agreement tended to increase in the second and third moments, with consequent reduction or maintenance of the average proportion of neutrality and disagreement.

We can say that both interventions were able to change the opinion of the participants, leading them to agreement regarding the evidence-based recommendations for the treatment of venous ulcers.

\section{REFERENCES}

1. Agale SV. Chronic leg ulcers: epidemiology, aetiopathogenesis, and management. Ulcers [Internet]. 2013 [cited 2015 Apr 20 ]. ID413604. Available from: http://www.hindawi.com/journals/ulcers/2013/413604/

2. Wound, Ostomy and Continence Nurses Society (WOCN). Guideline for management of wounds in patients with lower-extremity venous disease. Mount Laurel (NJ): WOCN, 2011. 58p.

3. Harding K, Dowsett C, Fias B, Jelnes R, Mosti G, Öien R, et al. Simplifying venous leg ulcer management: consensus recommendations. Int Wound J [Internet]. 2015 [cited 2015 Jul 04]. 28p. Available from: http://www.woundsinternational.com/ consensus-documents/view/simplifying-venous-leg-ulcer-management

4. Nelson EA, Bell-Syer SE. Compression for preventing recurrence of venous ulcers: review. Cochrane Database Syst Rev. 2014; 9:CD002303.

5. Rogers EM. Diffusion of innovations. 5 ed. New York: Free Press; 2003. 550p.

6. Hasson F, Keeney S, McKeena H. Research guidelines for the Delphi survey technique. J Adv Nurs. 2000;32(4):1008-15.

7. Munaretto LF, Corrêa HL, Cunha JAC. Um estudo sobre as características do método Delphi e de grupo focal como técnicas na obtenção de dados em pesquisas exploratórias. Rev Adm UFSM [Internet]. 2013 [cited 2014 Jan 10];6(1):9-24. Available from: http://periodicos.ufsm.br/reaufsm/article/view/6243/pdf

8. Ylönen M, Stolt M, Leino-Kilpi H, Suhonen R. Nurses' knowledge about venous leg ulcer care: a literature review. Int Nurs Rev [Internet]. 2014 [cited 2016 May 07];61(2):194-202. Available from: http://onlinelibrary.wiley.com/doi/10.1111/inr.12088/pdf

9. Carvalho EC, Cruz DALM, Herdman TH. Contribuição das linguagens padronizadas para a produção do conhecimento, raciocínio clínico e prática clínica da Enfermagem. Rev Bras Enferm[Internet]. 2013[cited 2016 May 07];66(esp):134-41. Available from: http://www.scielo.br/pdf/reben/v66nspe/v66nspea17.pdf

10. Kimmel HM, Robin AL. An evidence-based algorithm for treating venous leg ulcers utilizing the cochrane database of systematic reviews. Wounds [Internet]. 2013 [cited 2016 May 07];25(9):242-50. Available from: http://www.medscape.com/ viewarticle/811363_1

11. Ribeiro CTD, Fregonezi GAF, Resqueti VR, Dornelas de Andrade A, Dias FAL. Hydrocolloid dressings for healing venous leg ulcers. Cochrane Database Syst Rev [Internet]. 2014 [cited 2016 May 07]; CD010918. Available from: http://onlinelibrary.wiley. com/doi/10.1002/14651858.CD010918/pdf

12. O'Meara S, Martyn-St James M. Foam dressings for venous leg ulcers. Cochrane Database Syst Rev [Internet]. 2013 [cited 2016 May 07].CD009907.pub2. Available from: http://onlinelibrary.wiley.com/doi/10.1002/14651858.CD009907.pub2/abstract 
13. O'Meara S, Al-Kurdi D, Ologun Y, Ovington LG, Martyn-St James M, Richardson R. Antibiotics and antiseptics for venous leg ulcers. Cochrane Database Syst Rev [Internet]. 2013 [cited 2016 May 07]; (12):CD003557.pub4. 194p. Available from: http:// onlinelibrary.wiley.com/doi/10.1002/14651858.CD003557.pub4/pdf/.

14. Kelechi TJ, Johnson JJ, Yates S. Chronic venous disease and venous leg ulcers: an evidence-based update. J Vasc Nurs [Internet]. 2015 [cited 2016 May 02];33(2):36-46. Available from: https://www.ncbi.nlm.nih.gov/pubmed/26025146

15. Brambilla R, Aloisi D, Weingard I, Fioruzzi M, Heisterkamp T, Janthur E, Kurz P, Will K. VERUM - A European Approach for Successful Venous Leg Ulcer Healing. WHSA [Internet]. 2015 [cited 2016 May 07];8(1):34-6. Available from: http://www. woundhealingsa.co.za/index.php/WHSA/article/viewFile/190/361

16. Conselho Federal de Enfermagem (COFEN). Resolução $n^{\circ}$ 501/2015 - Regulamenta a competência da equipe de enfermagem no cuidado às feridas e dá outras providências. DOU n 241, 17 de dezembro de 2015, página 77 - Seção 1, 2015.

17. Sant'Ana SMSC, Bachion MM, Santos QR, Nunes CAB, Malaquias SG, Oliveira BGRB. Úlceras venosas: caracterização clínica e tratamento em usuários atendidos em rede ambulatorial. Rev Bras Enferm [Internet]. 2012 [cited 2016 May 07];65(4):637-44. Available from: http://oaji.net/articles/2014/672-1404745290.pdf 